\title{
Coluber Constrictor Bite to the Eye: A Novel Case Report of a Wild Snake Bite to the Eye in North America and Review of Literature
}

\author{
Sarah Madison Duff ${ }^{1}$, Andrew Bowman ${ }^{1}$, Charles Richard Blake ${ }^{1}$ \\ 1. Ophthalmology, University of Florida, Gainesville, USA
}

Corresponding author: Sarah Madison Duff, duffsm05@gmail.com

\begin{abstract}
Snake bites involving the eye are an uncommon cause of ocular trauma; herein, we present one of the few known instances of a snake bite directly to the globe, specifically by the way of a Coluber constrictor, also known as the "Black Racer."

In this case report, we describe a nine-year-old girl who presented immediately following a snake bite to the right eye. The patient's vision was unaffected despite visualized puncture wounds through the conjunctiva with associated near-total subconjunctival hemorrhage. The patient was taken to the operating room emergently for globe exploration. Circumferential peritomy and direct view to the sclera did not reveal any lacerations or puncture and subconjunctival vancomycin, gentamycin, and dexamethasone were administered intraoperatively. Post-operatively, the patient was discharged on a regimen of oral Cephalexin. Throughout multiple follow-ups, she continued to maintain excellent vision without sequelae.
\end{abstract}

Trauma to the globe via snake bite is an exceedingly rare occurrence. Upon literature review, three out of three cases involving venomous snakes resulted in "No Light Perception" vision despite anti-venom. While nonvenomous snake bites may lend a better visual outcome, if not treated properly they may also yield poor final visual potential. Methods of treatment include oral or subconjunctival antibiotic administration with or without a steroid or cycloplegic agent. All reported cases of nonvenomous cases ultimately resulted in excellent visual potential (20/40 or better) and no reports of endophthalmitis. As such, it is evident that identifying the species of snake is of the utmost importance when considering visual prognosis. Due to very few reported incidences of globe trauma via snake bite, there is no mainstay therapy for either the venomous or nonvenomous snake bite variety. Despite this, we encourage careful pursuance of the appropriate therapy on a case-by-case basis, considering operative treatment, antivenom (if necessary), and antibiotic coverage with possible cycloplegia and steroid administration.

Review began 12/02/2020 Review ended 12/11/2020 Published 12/17/2020

\section{(c) Copyright 2020}

Duff et al. This is an open access article distributed under the terms of the Creative Commons Attribution License CC-BY 4.0., which permits unrestricted use, distribution, and reproduction in any medium, provided the original author and source are credited.
Categories: Ophthalmology, Trauma

Keywords: snake, snakebite, bite, ocular injury, open globe, black racer, coluber constrictor

\section{Introduction}

Ocular injuries from snake bites are exceedingly uncommon. While snake bites elsewhere on the body have been known to cause ophthalmic manifestations, snake bites directly to the eye are extremely unusual and rarely reported. The range of complications from snake bites to the eye is largely dependent on the extent of damage and whether the snake is venomous or nonvenomous. This is the first reported case of a wild snake in North America directly biting the eye, as the four cases of penetrating globe injuries reported thus far in North America have been by pet snakes [1-4].

In the Southern United States and the State of Florida, there are six species of venomous snakes. The Coluber constrictor priapus, or more colloquially called the "Black Racer," is a common nonpoisonous snake that is unlikely to cause harm to a human unless provoked. We report a nine-year-old Caucasian female who presented to us after being bitten in the eye by a Southern Black Racer.

\section{Case Presentation}

A nine-year-old Caucasian female presented to the emergency department after being bitten in the eye by a snake. She stated that she was lizard hunting with her face near the ground when a snake launched toward her face. The snake, easily identified by the patient as a "Black Racer," bit her on the right eyelids and eye, prior to being hit away by the patient. She immediately told her father who brought her to the hospital directly.

On examination, the vision in both eyes was 20/20 without an affect pupillary defect (APD). Anterior chambers were deep in both eyes. Intraocular pressures were noted at 15 and $13 \mathrm{~mm}$ of mercury in the right and left eye, respectively, via iCare tonometer (Tiolat Oy, Helsinki, Finland). A near-total subconjunctival 


\section{Cureus}

hemorrhage, more significant nasally, was visualized in the right eye. Puncture sites through the conjunctiva were visualized inferonasally with a few bloody tears present. The sclera could not be visualized in this area. On the upper eyelid, skin incisions from the presumed snake fangs were visualized on the lateral right eyelid (Figure 1).

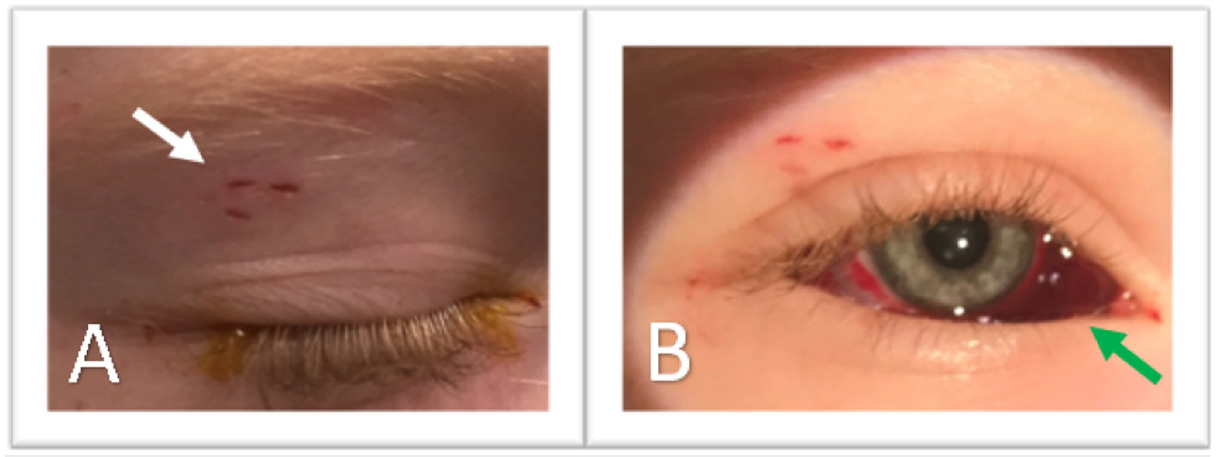

\section{FIGURE 1: Preoperative Photographs of the Right Eye}

(A) Closed eyelid of the right rye showing the temporal incisions (white arrow), presumably from the fangs of the Coluber constrictor priapus. (B) Subconjunctival hemorrhage (green arrow) larger under the nasal bulbar conjunctiva.

The intraocular examination was normal, without vitreous hemorrhage, disc edema, retinal hemorrhages, or retinal tears. Despite the excellent vision and unconcerning intraocular pressure, there was a strong concern for sclera perforations underlying the visualized conjunctival puncture sites. With the known history of a Southern Black Racer with needle-like fangs biting the right eye, and the visualized incisions on the lateral eyebrow and conjunctiva (without direct visualization of areas of sclera covered by blood), the decision was made for an examination under anesthesia and exploration of the globe. This was to ensure that an open globe and foreign bodies were not present. Prior to transfer to the operating room, the patient received intravenous (IV) clindamycin and IV ceftriaxone.

After sedation, the right eye was examined under the operating scope and the site of the conjunctival incisions was again visualized on the nasal bulbar conjunctiva. In the setting of the circumferential subconjunctival hemorrhage, the decision was made to perform a 360-degree limbal conjunctival peritomy in order to reflect the conjunctiva and Tenon's capsule and expose the sclera. Careful examination of the sclera, with emphasis placed on the inferior nasal sclera, did not reveal a scleral perforation or laceration, or a broken fang (Figure 2).
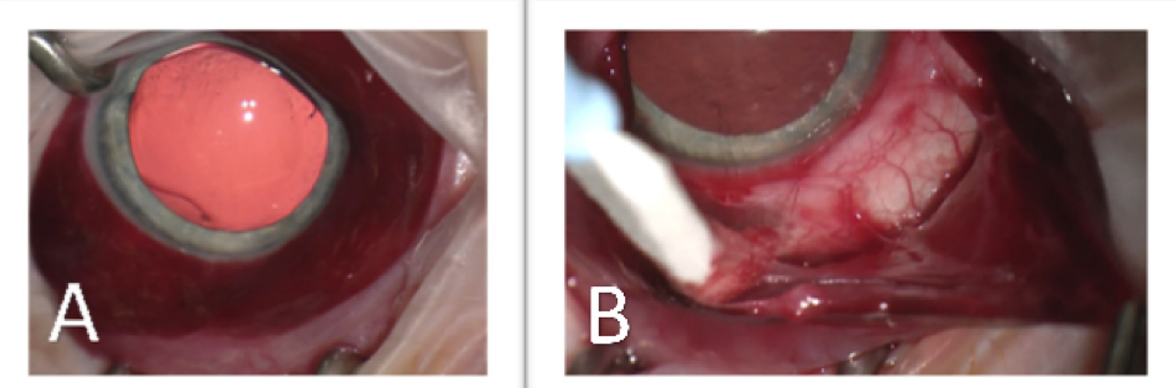

\section{FIGURE 2: Intraoperative Photos of the Right Eye}

(A) Subconjunctival hemorrhage with an area of concern inferonasally. (B) Exposed sclera in the inferonasal area without the visible site of penetration.

The tissue was reapproximated to the limbus with 8-0 Vicryl suture and the patient was given subconjunctival injections of Vancomycin, Gentamicin, and Dexamethasone. She was discharged from the hospital with an oral course of Cephalexin. At repeat follow-ups, the patient continued to have excellent vision without concern for ocular infection. Complete healing of the conjunctiva and tenon's capsule was found at a one-month follow-up.

\section{Discussion}


Vision-threatening complications after a snake bite are documented, although infrequent compared to the number of snake bites worldwide each year. Most importantly in prognosis is to determine if the snake is venomous or nonvenomous. The patient may or may not be able to do this due to difficulties visualizing or identifying the snake. Venomous snake bites may cause ocular problems, even if the site of the bite is far from the patient's eyes, or worse may cause death without treatment. Snake venom is a complex blend of proteins and peptides, unique to each species of snake. Venom effects may be differentiated into neurotoxic effects (including paralysis and pain), hemotoxic effects (including changes in blood coagulation, fibrinolysis, and platelet aggregation), and cytotoxic effects (including inflammation and necrosis) [5]. Understanding which category each snake's venom most closely aligns with can help the physician to treat the patient. These systemic effects related to bites distant from the eyes have been reported in association with multiple diverse ocular complications, including (but not limited to): central retinal artery occlusions [6], uveitis, acute angle-closure [7], extraocular muscle palsies [8,9], optic neuritis, and optic nerve atrophy [10]. Some of these ocular complications may improve over time. In our case, the patient was able to immediately identify the snake and clarify with certainty that the snake was nonvenomous.

Direct snake bites to the eyes are equally, if not more, infrequent a cause of vision loss than snake bites elsewhere. A PubMed literature search was performed on November 6, 2020, with restrictions only for English-language articles or those translated to English, and articles with at minimum an abstract accessible through the University of Florida, using the terms "snake," "bite," and "eye." Nine cases of ocular injuries from a direct snakebite injury to the eye were reported (Table 1 ) [1-4,11-15]. 


\section{Cureus}

\begin{tabular}{|c|c|c|c|c|c|c|c|c|}
\hline Authors & Year & Area & Type of Snake & $\begin{array}{l}\text { Venomous } \\
\text { (Y/N) }\end{array}$ & $\begin{array}{l}\text { Wild } \\
(\mathrm{Y} / \mathrm{N})\end{array}$ & Injury & $\begin{array}{l}\text { Final } \\
\text { VA }\end{array}$ & Treatment \\
\hline $\begin{array}{l}\text { Brandão et } \\
\text { al. [11] }\end{array}$ & 1993 & Brazil & $\begin{array}{l}\text { Lance-headed } \\
\text { Viper (Bothrops } \\
\text { moojeni) }\end{array}$ & Yes & Yes & $\begin{array}{l}\text { Periorbital swelling, exophthalmos, fang } \\
\text { marks in the upper eyelid, necrosis of } \\
\text { ocular tissue }\end{array}$ & NLP & $\begin{array}{l}\text { Antivenom, stabilization, intravenous } \\
\text { penicillin and ampicillin, early enucleation }\end{array}$ \\
\hline $\begin{array}{l}\text { Kleinman et } \\
\text { al. [3] }\end{array}$ & 1998 & $\begin{array}{l}\text { United } \\
\text { States }\end{array}$ & Boa constrictor & No & No & $\begin{array}{l}\text { Eyelid laceration, full-thickness corneal } \\
\text { punctures, conjunctival puncture }\end{array}$ & $20 / 25$ & $\begin{array}{l}\text { Intravenous ampicillin/sulbactam, topical } \\
\text { ofloxacin, intravenous vancomycin, } \\
\text { ceftazidime, and clindamycin, surgical repair }\end{array}$ \\
\hline $\begin{array}{l}\text { Sheard and } \\
\text { Smith [12] }\end{array}$ & 2003 & England & Boa constrictor & No & No & $\begin{array}{l}\text { Eyelid laceration, full-thickness corneal } \\
\text { laceration, full-thickness scleral perforation }\end{array}$ & $20 / 30$ & $\begin{array}{l}\text { Surgical repair, topical antibiotics, systemic } \\
\text { antibiotics, topical steroids }\end{array}$ \\
\hline $\begin{array}{l}\text { Chen et al. } \\
\text { [13] }\end{array}$ & 2003 & Taiwan & $\begin{array}{l}\text { Hundred pacer } \\
\text { (Deinagkistrodon } \\
\text { actus) }\end{array}$ & Yes & Yes & $\begin{array}{l}\text { Diffuse subconjunctival hemorrhage, } \\
\text { exophthalmos, corneal edema, full- } \\
\text { thickness scleral laceration, necrosis of } \\
\text { ocular tissue }\end{array}$ & NLP & $\begin{array}{l}\text { D. acutus antivenom, stabilization, early } \\
\text { evisceration }\end{array}$ \\
\hline $\begin{array}{l}\text { Korn and } \\
\text { Korn [2] }\end{array}$ & 2005 & $\begin{array}{l}\text { United } \\
\text { States }\end{array}$ & Boa constrictor & No & No & $\begin{array}{l}\text { Pinpoint area of full-thickness corneal } \\
\text { laceration within LASIK flap }\end{array}$ & $20 / 25$ & $\begin{array}{l}\text { Cyanoacrylate tissue adhesive, surgical } \\
\text { exploration, subconjunctival cefazolin and } \\
\text { gentamicin, oral gatifloxacin, topical } \\
\text { gatifloxacin }\end{array}$ \\
\hline $\begin{array}{l}\text { Ashwin et } \\
\text { al. [14] }\end{array}$ & 2009 & England & Python molurus & No & No & $\begin{array}{l}\text { Full-thickness corneoscleral laceration, } \\
\text { hyphema, retinal tear }\end{array}$ & $20 / 30$ & $\begin{array}{l}\text { Surgical repair, intravenous ceftriaxone, } \\
\text { topical ofloxacin } 0.3 \% \text {, topical } \\
\text { betamethasone } 0.1 \% \text {, topical } \\
\text { cyclopentolate, argon laser retinopexy }\end{array}$ \\
\hline $\begin{array}{l}\text { Muthusamy } \\
\text { and Flynn } \\
\text { [15] }\end{array}$ & 2011 & England & Boa constrictor & No & No & Full-thickness corneal laceration, hyphema & $20 / 30$ & $\begin{array}{l}\text { Surgical repair, topical dexamethasone } \\
0.1 \% \text {, topical ofloxacin, oral ciprofloxacin, } \\
\text { oral metronidazole }\end{array}$ \\
\hline $\begin{array}{l}\text { Yung et al. } \\
\text { [4] }\end{array}$ & 2018 & $\begin{array}{l}\text { North } \\
\text { America }\end{array}$ & $\begin{array}{l}\text { Western } \\
\text { diamondback } \\
\text { rattlesnake } \\
\text { (Crotalus atrox) }\end{array}$ & Yes & No & $\begin{array}{l}\text { Full-thickness scleral laceration, uveal } \\
\text { tissue prolapse, choroidal rupture }\end{array}$ & NLP & $\begin{array}{l}\text { Crotalidae FabAV, stabilization, surgical } \\
\text { repair, intravenous levofloxacin }\end{array}$ \\
\hline $\begin{array}{l}\text { Behrens et } \\
\text { al. [1] }\end{array}$ & 2018 & $\begin{array}{l}\text { United } \\
\text { States }\end{array}$ & $\begin{array}{l}\text { Burmese Python } \\
\text { (Python } \\
\text { bivittatus) }\end{array}$ & No & No & $\begin{array}{l}\text { Partial and full-thickness corneal laceration, } \\
\text { hyphema, anterior lens capsule disruption }\end{array}$ & $20 / 30$ & $\begin{array}{l}\text { Intravenous cefazolin, } \\
\text { tobramycin/dexamethasone ointment, } \\
\text { topical moxifloxacin } 0.5 \% \text {, topical atropine, } \\
\text { cataract extraction }\end{array}$ \\
\hline
\end{tabular}

\section{TABLE 1: Literature Review of Reported Ocular Injuries from Direct Snake Bite to the Eye}

VA: visual acuity, NLP: no light perception, LASIK: laser-assisted in situ keratomileusis, FabAV: fragment antigen-binding antivenom.

Of the cases in the literature, only two of the nine cases (22\%) occurred in the wild [11,13], while the other cases were attacks from pets or other caged snakes. Three cases (33\%) were from venomous snakes $[4,11,13]$. Each of these patients required anti-venom and stabilization. Despite one of these three individuals being able to physically retain his eye [4], all three cases (100\%) of a venomous snake bite to the eye resulted in nonlight perception (NLP) vision or removal of the eye.

Of the nonvenomous case reports, all six cases (100\%) received some form of systemic antibiotic therapy, despite no consistency in antibiotics chosen and no consistency on if intravenous or oral systemic therapy was preferred. Standard of care for nonvenomous site bites elsewhere on the body does not include empiric antibiotics to prevent secondary infections after snakebites, although tetanus prophylaxis should be provided as needed. Of those with reported drug selections (five cases) [1-3,14-15], each patient received treatment with a topical fluoroquinolone, although the specific drug of choice varied. Kleinman et al. discussed the likelihood of bacterial stomatitis, especially in captive snakes, as a reason for antibacterial therapy in ocular snakebite injuries and found that in the pet Boa constrictor case, cultures from the teeth of the snake showed multiple species of Gram-negative rods [3]. Other medications were also utilized. Three cases (50\%) received a topical steroid [1,12,15], one case received subconjunctival antibiotics intraoperatively [2], and two cases (33\%) received a topical cycloplegic $[1,14]$. Despite venomous snake bites to the eye having a poor visual prognosis, each of the nonvenomous cases ultimately ended with a bestcorrected visual acuity of better than $20 / 40$. It should be noted, however, that nonvenomous ocular snake 
bite cases may have had a better initial, presenting visual acuity. Regardless, none of the reported cases ultimately were reported to have endophthalmitis.

In our case, despite no reported case of endophthalmitis after a nonvenomous ocular snake bite, we treated with subconjunctival antibiotic therapy due to the concern that the fangs had penetrated the globe prior to the globe possibly self-sealing.

\section{Conclusions}

The definitive management of a snake bite directly to the eye has yet to be fully elucidated, despite the slowly growing collection in literature. We report the first case of a wild snake biting a patient in the United States in the eye and the first reported case of a Coluber constrictor priapus managing to bite a patient's eye. Despite no report of endophthalmitis after a nonvenomous ocular snake bite, we would encourage careful consideration by the practitioner prior to deferring either topical or subconjunctival antibiotic therapy. While we decided to explore the globe with surgery due to the areas of the sclera that could not be seen on examination and the knowledge that Black Racers have very long and thin fangs and use them to strike with much force and speed, due to no reports of endophthalmitis after a nonvenomous snake bite, an argument could be made to wait and watch an eye presenting similarly to ours, rather than perform an intraoperative exploration.

\section{Additional Information \\ Disclosures}

Human subjects: Consent was obtained by all participants in this study. Conflicts of interest: In compliance with the ICMJE uniform disclosure form, all authors declare the following: Payment/services info: The University of Florida was provided a grant from Research to Prevent Blindness, otherwise, we have no conflicts of interest to disclose. Financial relationships: All authors have declared that they have no financial relationships at present or within the previous three years with any organizations that might have an interest in the submitted work. Other relationships: All authors have declared that there are no other relationships or activities that could appear to have influenced the submitted work.

\section{Acknowledgements}

The University of Florida was provided a grant from Research to Prevent Blindness.

\section{References}

1. Behrens AW, Jones MH, Lowery RS: Pediatric ocular injury secondary to a Burmese python bite . J AAPOS. 2018, 22:399-400. 10.1016/j.jaapos.2018.03.002

2. Korn BS, Korn TS: Cyanoacrylate repair of laser in situ keratomileusis corneal flap perforation by a snake bite. J Cataract Refract Surg. 2005, 31:2224-2226. 10.1016/j.jcrs.2005.04.044

3. Kleinman DM, Dunne EF, Taravella MJ: Boa constrictor bite to the eye . Arch Ophthalmol. 1998, 116:949950. 10.1001/archopht.116.7.949

4. Yung ES, Crossan A, Honkanen R, Rosenberg JB, Kaplowitz K: Penetrating ocular injury by Western diamondback rattlesnake. Can J Ophthalmol. 2018, 53:134-135. 10.1016/i.jcjo.2017.10.017

5. Ferraz CR, Arrahman A, Xie C, Casewell NR, Lewis RJ, Kool J, Cardoso FC: Multifunctional toxins in snake venoms and therapeutic implications: from pain to hemorrhage and necrosis. Front Ecol Evol. 2019, 7:218. 10.3389/fevo.2019.00218

6. Jalali S, Padhi TR, Bansal R, Sahoo K, Basu S, Mathai A: Visual loss with inner retinal dysfunction, after snake bite: two case reports. Doc Ophthalmol. 2013, 127:155-163. 10.1007/s10633-013-9390-1

7. Aye MT, Naing T, Myint KT: Unusual ocular manifestations following viper bite. BMJ Case Rep. 2018, 2018:bcr2018225040. 10.1136/bcr-2018-225040

8. Takeshita T, Yamada K, Hanada M, Oda-Ueda N: Case report: extraocular muscle paresis caused by snakebite. Kobe J Med Sci. 2003, 49:11-15.

9. Igari R, Iseki K, Abe S, et al.: [Binocular diplopia and ptosis due to snakebite (Agkistrodon blomhoffi "mamushi") - a case report]. Brain Nerve. 2010, 62:273-277.

10. Guttmann-Friedmann A: Blindness after snake-bite. Br J Ophthalmol. 1956, 40:57-59.

11. Brandão EO, de Bastos HC, Nishioka SA, Silveira PV: Lance-headed viper (Bothrops moojeni) bite wounding the eye. Rev Inst Med Trop Sao Paulo. 1993, 35:381-383. 10.1590/s0036-46651993000400014

12. Sheard RM, Smith GT: Penetrating eye injury following a snake attack . Eye (Lond). 2003, 17:279-280. 10.1038/sj.eye.6700309

13. Chen CC, Yang CM, Hu FR, Lee YC: Penetrating ocular injury caused by venomous snakebite . Am J Ophthalmol. 2005, 140:544-546. 10.1016/j.ajo.2005.03.005

14. Ashwin PT, Mehta P, Tailor R, McDonnell PJ: Challenges in the management of ocular snake-bite injuries . Int Ophthalmol. 2010, 30:633-635. 10.1007/s10792-009-9341-8

15. Muthusamy K, Flynn TH, Mearza AA: A rare case of penetrating ocular injury secondary to a boa constrictor bite. Cont Lens Anterior Eye. 2012, 35:46-47. 10.1016/j.clae.2011.08.002 